\title{
Pengaruh Kualitas Produk dan Harga terhadap Kepuasan Konsumen (Studi pada Usaha Cuci Mobil "Salem" Desa Sumokembangsri Kecamatan Balongbendi Kabupaten Sidoarjo)
}

\author{
Mohamad johan efendi \\ Universitas mayjen sungkono Mojokerto \\ Devi iriandha widyastuti \\ Universitas mayjen sungkono Mojokerto \\ Mohamadjohanefendi@gmail.com \\ deviiriandhaw@gmail.com
}

\begin{abstract}
Abstrak
Penelitian ini bertujuan untuk mengetahui pengaruh variabel kualitas produk (X1) dan harga (X2) terhadap kepuasan konsumen (Y) baik secara parsial, simultan dan dominan .Pada penelitian ini, ukuran sampel diambil dengan menggunakan rumus Slovin berjumlah 69 orang yang berasal dari konsummen. Teknik pengambilan sampel menggunakan probability sampling. Data diambil menggunakan kuesioner yang diukur dengan skala Likert. Pada Penelitian ini menggunnakan analisis regresi linier berganda dengan bantuan program SPSS versi 16.0. Hasil penelitian ini menunjukkkan bahwa variabel kualitas produk (X1) dan harga (X2) berpengaruh secara simultan terhadap kepuasan konsumen Variabel kualitas produk (X1) dan variiabel harga ( X2 ) tidak berpengaruh secara parsiial terhadap kepuasaan konsumen.dan variabel kualitas produk yang berpengaruh paling dominan terhadap kepuasan konsumen.
\end{abstract}

Kata Kunci: Kualitas produk, harga, kepuasan konsumen

\section{Pendahuluan}

Seiring dengan perkemmbangan dunia bisnis otomotif di negara Indonesia, kebutuhan transportasi di indonesia terus meningkat, diikuti dengan bertumbuhnya jumlah penduduk tiap tahun. Dengan terus meningkatnya jumlah kendaraan berdampak positif pada usaha cuci mobil dan motor. Karena dengan adanya usaha cuci mobil atau motor bisa membantu , pelanggan yang sibuk dengan rutinitas, bisa mencucikan kendaraan ke salah satu tempat cuci motor. Cuci mobil "salem " bukan hanya buka jasa cuci mobil dan motor , usaha ini membuka jasa salon mobil yang mana target pasar nya kalangan pemuda pemudi pencinta otomotif clean,

Tabel 1 .Pendapatan cuci mobil " salem “

\begin{tabular}{|l|l|l|}
\hline 1 & 2016 & Rp. 39.240 .000 \\
\hline 2 & 2017 & Rp. 44.640 .000 \\
\hline 3 & 2018 & Rp. 45.889 .000 \\
\hline 4 & 2019 & Rp. 47.233 .000 \\
\hline
\end{tabular}

Sumber : Pendapatan cuci mobil "salem “ 2016-2019

Gambar 1 menunjukkan bahwa nilai pendapatan " cuci mobil "salem stabil. Walaupun demikian, ternyata harus menghadapi bertambahnya pesaing yang mampu menjadi kompetitor bagi usaha di bidang sejenis.cuci mobil salem .Hal tersebut mendorong sejenis. untuk 
sejenis.cuci mobil salem terus memperbaikii kemampuan dalam mempengaruhi kepuasan konsumen. Kepuasan konsumen layak diteliti, karena dengan kepuasan konsumen, ,sejenis.cuci mobil salem dapat mempertahankan konsumen dari penawaran menarik yang dimiliki kompetitor serta memungkinkan konsumen untuk menyebaarluaskan kesan positif mengenai sejenis.cuci mobil salem kepada orang lain.

Berdasarkan latarbelakang tersebut, penelitian ini bertujuan untuk menganalisis pengaruh variabel kualitas produk dan harga terhadap kepuasan konsumen pada cuci mobil salem di desa sumokembangsri kecamatan balongbendo kanbupaten sidoarjo

Tujuan penelitian ini adalah

a. Untuk menganalisis pengaruh variabel kualitas produk dan variabel harga secara parsial terhadap kepuasan konsumen pada cuci mobil "salem "

b. Untuk menganalisis pengaruh variabel kualitas produk dan variabel harga secara simultan terhadap kepuasan konsumen pada cuci mobil "salem "

c. Untuk menganalisis variabel mana yang paling dominan diantara Kualitas produk dan harga terhadap kepuasan konsumen pada cuci mobil "salem "

Manfaat yang diperoleh dari penelitian ini yaitu bisa dijadikan evaluasi dan bahan dalam pengambilan keputusan dengan tujuan pelayanan yang terbaik kepada konsumen.

\section{Landasan teori dan Hipotesis}

\section{Kualitas Produk}

Menurut Wibowo (2014), kualitas didefinisikan sebagai memenuhi atau melebihi harapan pelanggan. Berdasarkan Heizer dan Render (dalam Wibowo 2014), mendefinisikan kualitas sebagai kemampuan produk atau jasa memenuhi kebutuhan pelanggan.

Menurut Kotler and Armstrong dalam (Putro et al., 2014) menyatakan kualitas produk sebagai "the ablity of a product to perform its functions. Its includes the product's overall durability, reliability, precision, ease of operation and repair, and other valued attributes" yang artinya kualitas produk berhubungan erat dengan kemampuan produk untuk menjalankan fungsinya, termasuk keseluruhan produk,, keandalan, ketepatan, kemudahan pengoperasian dan perbaikan, dan atribut bernilai lainnya. Berdasarkan informasi- informasi tersebut, dapat dipahami bahwa kualitas produk merupakan karakteristik dari barang dan jasa yang mempunyai kemampuan untuk memenuhi kebutuhan, yang merupakan gabungan dari keandalan, ketepatan, kemudahan, pemeliharaan dari suatu produk. Indikator yang digunakan untuk mengukur kualitas produk, menurut Menurut Saleleng et al., (2014), yaitu:

1. Kinerja (performance),.

2. Kehandalan (reliability),.

3. Keistimewaan (feature),

4. Kemampuan pelayanan (serviceability),

5. Daya tahan (durability),

\section{Harga}

Zakaria (2013) menjelaskan bahwa harga adalah sejumlah uang yang dibutuhkan untuk mendapat sejumlah kombinasi dari barang beserta pelayannya. Lenzun et al., (2014) menjelaskan bahwa harga adalah pernyataan nilai dari suatu produk yang merupakan elemen bauran pemasaran yang paling fleksibel. Menurut Manus dan Lumanauw (2015) .menyatakan harga mempunyai peranan penting dalam proses pengambilan keputusan yaitu peranan alokasi dari harga adalah membantu para pembeli untuk memperoleh produk atau jasa dengan manfaat terbaik berdasarkan kekuatan daya belinya. Berdasarkan informasi-informasi tersebut, dapat 
dipahami bahwa harga adalah sejumlah uang yang dibutuhkan untuk mendapatkan pernyataan nilai dari suatu produk atau jasa sesuai dengan kualitas dan manfaat yang diberikan dengan dipengaruhi oleh faktor-faktor psikologis dan faktor-faktor lain yang mempengaruhi harga itu sendiri.

\section{Kepuasan Konsumen}

Nugroho (2015) menjelaskan bahwa kepuasan konsumen merupakan salah satu elemen penting dalam peningkatan kinerja pemasaran dalam suatu perusahaan. Kepuasan yang dirasakan oleh pelanggan dapat meningkatkan intensitas membeli dari pelanggan tersebut. Dengan terciptanya tingkat kepuasan pelanggan yang optimal maka mendorong terciptanya loyalitas di benak pelanggan yang merasa puas tadi. Kepuasan diukur dari sebaik apa harapan pelanggan dipenuhi. Sedangkan loyalitas pelanggan adalah ukuran semau apa pelanggan melakukan pembelian lagi

\section{Hipotesis}

Jahanshahi et al., (2011) menjelaskan bahwa pada penelitian yang dilakukan menunjukkan hasil bahwa kualitas layanan dan kualitas produk berpengaruh pada kepuasan pelanggan dan juga ada hubungan positif antara kualitas layanan dan kualitas produk dengan kepuasan dan loyalitas pelanggan dalam konteks industri otomotif India. Sehingga dapat dimungkinkan bahwa terdapat hubungan antara kualitas produk terhadap kepuasan konsumen. :Lonardo dan Soelasih (2014) menunjukkan bahwa terdapat pengaruh positif terhadap kualitas produk dan harga pada kepuasan kosumen lapis legit dalam membangun word of mouth positif. Sehingga dapat dimungkinkan terdapat hubungan antara harga terhadap kepuasan konsumen. Maka dari itu dapat disimpulkan hipotesis sebagai berikut:

H1 : Kualitas produk berpengaruh signifikan secara parsial terhadap kepuasan konsumen H2 : Harga berpengaruh signifikan secara parsial terhadap kepuasan konsumen H3 : Kualitas produk dan harga berpengaruh signifikan secara Simultan terhadap kepuasan konsumen

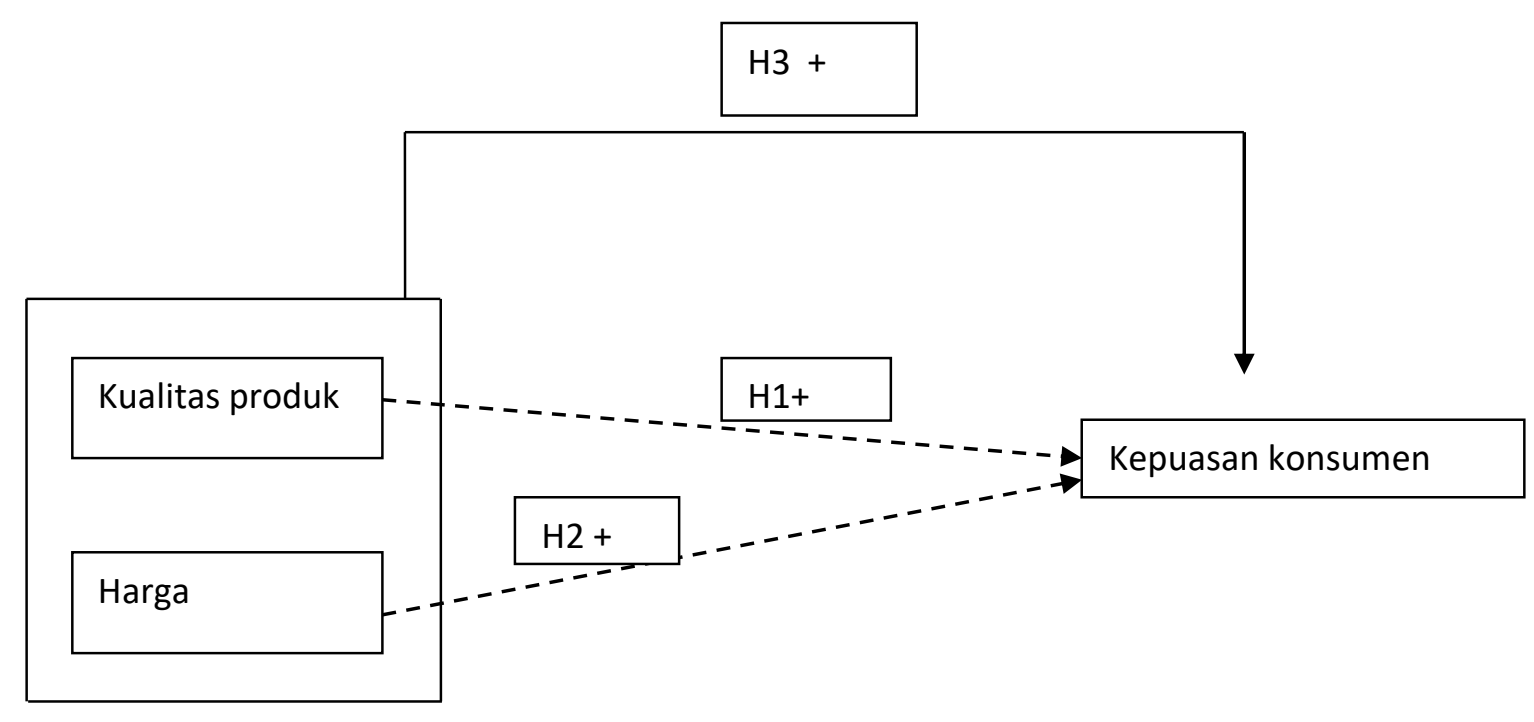

Gambar 1 , Kerangka Konsep 


\section{Metode Penelitian}

Penelitian ini menggunakan pendekatan kuantitatif, yang mana langkah awal akan menyebar angket kuisioner dan diolah menggunakan statistic atau bantuan n program SPSS

Devinisi operasional variabel merupakan indikator yang digunakan dalam penyusunan penelitian ,,, dalam penelitian ini terdapat 3 variabel yang di teliti yaitu kualitas produk, harga sebagai variabel independen dan kepuasan konsumen sebagai variabel dependent.untuk pengolahan data diperlukan unsure lain yan berhubungan dengan variabel seperti konsep variabel, indikator. Operasionalisasi variabel untuk penelitian ini adalah sebagai berikut :

1. Kualitas produk adalah karakteristik dari suatu produk dalam kemampuanya untuk memenuhi kebutuhan - kebutuhan yang telah di tentukan dan mempunyai sifat laten ( david garvin dalam tjiptono 2016 )

Indikator : kesan kualitas produk, daya tarik tampilan produk,konsistensi produk,kualitas bahan produk, ciri khas produk .

2. Harga adalah jumlah semua nilai yang diberikan oleh pelanggan untuk mendapatkan keuntungan dari memiliki atau mengguanakan suatu produk atau jasa.

Indikator : kesesuaian harga, daya saing harga, kualitas produk,keterjankauan harga ( kotler 2008 )

3. Kepuasan konsumen adalah perasaan senang atau kecewa seseorang muncul setelah membandingkan kinerja atau hasil produk yang dipikirkan terhadap kinerjayang di harapkan.( kotler 2008 )

Indikator : kualitas jasa, Kualitas CS, harga,akses yang mudah,

Jenis dan sumber data adalah jenis data baik satu atau lebih dari satu yang dibutuhkan guna mendukung keakuratan penyajian suatu penelitian,sehingga dapat diketahui asal dari data tersebut,macam-macam dari sumber data adalah sebagai berikut

Data primer adalah data yang diperoleh secara langsung dari sumber aslinya.data primer secara khusus dikumpulkan untuk menjawab pertanyaan penelitian.( kuisioner ) data primer biasanya di peroleh dari survey lapangan yang menggunakan semua metode pengumpulan data ordinal ( Sugiono,2013)

Terdapat dua cara untuk mengumpulkan data yang akan diperlukan untuk melakukan analisis dalam penelitian ini,yaitu sebagai berikut :

1. pengumpulan data primer

Pengumpulan data primer dalam penelitian ini dilakukan dengan menggunakan teknik sebagai berikut :

a. kuisioner teknik pengumpulan data yang digunakan dalam penelitian ini adalah teknik pengumpulan data dengan menggunakan kuisioner. Kuisioner adalah teknik pengumpulan data yang dilakukan dengan cara member seperangkat pertanyaan atau pernyataan tertulis kepada responden untuk dijawab.kuisioner merupakan teknik pengumpulan data yang efisien bila peneliti tahu dengan pasti variable yang akan diukur dan tahu yang bisa diharapkan dari responden.

Skala yang digunakan dalam penelitian ini adalah skala likert .menurut (Ghozali, 2005) ,skala likert adalah skala yang berisi yang 5 ( lima ) tingkat prefrensi jawaban dengan pilihan sebagai berikut : 
1 = sangat tidak setuju

2 = tidak setuju

3 = cukup

4 = setuju

5 = sangat setuju

Penelitian ini terdiri dari 3 variabel bebas (X) yakni kualitas produk (X1), harga (X2), sedangkan variabel terikat kepuasan konsumen (Y). Subyek dalam penelitian ini adalah konsumen Cuci mobil " salem " adapun jumlah populasi konsumen Cuci mobil "salem " terdiri dari 220 pelanggan. Sedangkan penetapan jumlah sampel yang dilakukan dengan menggunakan rumus dari Slovin, yang diambil dari buku Umar (2002 )yaitu sebagai berikut :

$$
\mathrm{n}=\frac{\mathrm{N}}{1+\mathrm{Ne}^{2}}
$$

Dimana: $\mathrm{n} \quad=$ Ukuran sampel

$\mathrm{N} \quad=$ Ukuran populasi

$\mathrm{e} \quad=$ Tingkat kesalahan dalam memilih anggota sampel yang ditolelir

(tingkat kesalahan yang diambil dalam sampling ini adalah sebesar 10\%)

$$
\begin{aligned}
\text { Maka } & =\frac{220}{1+220(0.1)^{2}} \\
& =\frac{220}{3,2} \\
\mathrm{n} & =69
\end{aligned}
$$

Berdasarkan perhitungan diatas maka penulis menetapkan anggota sampel penelitian (n) yang digunakan dalam penelitian ini adalah 69 responden.Pengumpulan data pada penelitian ini menggunakan angket atau kuesioner dengan lima pilihan jawaban yakni sangat setuju (SS), setuju (ST), ragu-ragu (RG), tidak setuju (TS), dan sangat tidak setuju (STS). Penelitian ini menggunakan teknik analisis data regresi ganda. Sebelum menggunakan teknik regresi ganda, maka sebelumnya dilakukan analisis pada data-data yang dikumpulkan, dengan mengukur apakah data bersifat homogen atau tidak dengan cara uji Normalitas Data, uji Multikolinieritas, uji Heteroskedastisitas. Model analisis data yang digunakan untuk menjawab hipotesis adalah regresi linier berganda dengan pengolahan data menggunakan software SPSS (Statistical Package for Social Science)

\section{Validitas dan Reliabilitas}

Suatu skala pengukuran disebut valid bila melakukan apa yang seharusnya dilakukan dan mengukur apa yang seharusnya diukur. Bila skala pengukuran tidak valid maka tidak bermanfaat bagi peneliti karena tidak mengukur atau melakukan apa yang seharusnya dilakukan. Uji validitas yang digunakan dalam penelitian ini adalah dengan menggunakan pearson correlation. Jika nilai sig kurang dari 0,05 maka dinyatakan valid (Kuncoro, 2013).

Reliabilitas menunjukkan konsistensi dari suatu skor (skala pengukuran). Reliabilitas berbeda dengan validitas, reliabilitas memusatkan perhatian pada masalah konsistensi dan lebih memperhatikan masalah ketepatan (Kuncoro, 2013). Uji reliabilitas yang digunakan dalam penelitian ini adalah dengan menggunakan cronbach alpha, dengan pengukuran dikatakan reliabel apabila cronbach alpha $>0,6$ dan cronbach alpha if item deleted $<$ cronbach alpha.

\section{Uji Multikoliniearitas}

Uji Multikolinearitas adalah keadaan dimana antara dua variabel independen atau lebih pada model regresi terjadi hubungan linier yang sempurna atau tidak mendekati sempurna (Priyatno, 2013). Uji multikolinearitas diukur dengan menggunakan nilai VIF (Variance 
Inflation Factor). Jika nilai VIF kurang dari 10, maka gejala multikolinearitas tidak terjadi. Jika nilai VIF lebih besar dari 10, maka terjadi multikolinearitas

\section{Uji Heteroskedastisitas}

Uji Heteroskedastisitas adalah keadaan dimana terjadinya ketidaksamaan varian dari residual pada model regresi (Priyatno, 2013). Metode yang digunakan dalam uji heteroskedastisitas adalah uji Glejser. Jika nilai sig. pada uji Glejser untuk setiap variabel bebas lebih besar dari 0,05 maka tidak terjadi heteroskedastisitas atau disebut varians residual yang sama (homoskedastisitas). Jika nilai sig. pada uji Glejser untuk setiap variabel bebas lebih kecil dari 0,05 maka terjadi heteroskedastisitas atau disebut varians residual tidak sama.

\section{Uji Normalitas}

Uji Normalitas merupakan syarat dalam analisis parametrik dimana distribusi data harus normal (Priyatno, 2013). Pengujian menggunakan uji Kolmogorov-Smirnov untuk mengetahui apakah distribusi data pada tiap-tiap variabel normal atau tidak. Jika nilai signifikansi pada uji Kolmogorov-Smirnov lebih besar dari 0,05 maka residual berdistribusi normal. Sebaliknya bila nilai signifikansi pada uji Kolmogorov-Smirnov lebih kecil dari 0,05 maka residual tidak berdistribusi normal.

\section{Uji F}

Menurut Kuncoro (2013), uji statistik F pada dasarnya menunjukkan apakah semua variabel bebas yang dimasukkan dalam model mempunyai pengaruh secara bersama- sama terhadap variabel terikat.

\section{Analisa Koefisien Kolerasi (r) dan Determinasi (r2)}

Koefisien kolerasi berganda (r) adalah perkiraan seberapa jauh hubungan dua atau lebih variabel bebas terhadap variabel terikat. Menurut Kuncoro (2013) koefisien determinasi (r2) pada intinya mengukur seberapa jauh kemampuan model dalam menerangkan variasi variabel terikat. Tingkat keeratan hubungan (koefisien kolerasi) bernilai di antara 0-1. Jika hasil $\mathrm{r}$ mendekati angka satu (1), maka pengaruh variabel bebas terhadap variabel terikat semakin kuat. Jika hasil $\mathrm{r}$ mendekati angka nol (0), maka hubungan variabel bebas semakin lemah terhadap variabel terikat. Nilai r2 juga berada di antara $0-1$. Jika nilainya mendekati 1 maka kemampuan model menerangkan variabel terikat semakin baik.

\section{Uji t}

Menurut Kuncoro (2013) uji statistik t pada dasarnya menunjukkan seberapa jauh pengaruh satu variabel penjelas secara individual dalam menerangkan variabel terikat.

\section{Analisis Regresi Berganda}

Menurut Priyatno, (2013), analisis ini untuk meramalkan variabel dependen jika variabel independen dinaikkan atau diturunkan Persamaan regresinya adalah sebagai berikut:

$\mathrm{Y}=\alpha+\beta 1 X 1+\beta 2 X 2+\varepsilon$

Keterangan:

Y : Variabel terikat (kepuasan konsumen)

$\alpha:$ Konstanta

$\beta 1$ : Koefisien regresi Kualitas Produk 
$\beta 2$ : Koefisien regresi Harga

$\mathrm{X} 1$ : Kualitas Produk

$\mathrm{X} 2$ : Harga

$\varepsilon:$ Residual

\section{Hasil dan pembahasan}

Dalam pemecahan masalah yang dikaji oleh penulis, maka penulis menggunakan analisis deskriptif kuantitatif. Kemudian melakukan penghitungan data yang dihasilkan dari penyebaran kuesioner kepada responden dengan menggunakan program SPSS 16. Hasil penghitungan data tersebut digunakan untuk membuktikan pengaruh tidaknya variabel kualitas produk dan harga terhadap kepuasan konsumen baik itu secara simultan maupun secara parsial. Adapun teknik pengukuran yang digunakan antara lain:

\section{Hasil uji validitas}

Uji validitas digunakan untuk mengetahui apakah data yang digunakan valid atau tidak. Cara mengukur validitas dengan melihat pearson correlation, dimana jika hasil penghitungan skor total nilai signifikasi $<0,05$

Tabel 2. Hasil Uji Validitas Pada Variabel X1,X2, Y

\begin{tabular}{|c|c|c|c|c|}
\hline Variabel & Item & $\mathbf{r}$ & Sig & Keterangan \\
\hline \multirow[t]{5}{*}{$\begin{array}{c}\text { Kualitas produk } \\
\text { ( X1) }\end{array}$} & x1_1 & 0,708 & 0,000 & Valid \\
\hline & $\mathrm{x} 1 \_2$ & 0,872 & 0,000 & Valid \\
\hline & $\mathrm{x} 1 \_3$ & 0,601 & 0,000 & Valid \\
\hline & x1_4 & 0,821 & 0,000 & Valid \\
\hline & $\mathrm{x} 1 \_5$ & 0,544 & 0,000 & Valid \\
\hline \multirow[t]{5}{*}{ harga ( X2 ) } & $\mathrm{x} 2 \_1$ & 0,839 & 0,000 & Valid \\
\hline & $\mathrm{x} 2 \_2$ & 0,766 & 0,000 & Valid \\
\hline & $x 2 \_3$ & 0,713 & 0,000 & Valid \\
\hline & $\mathrm{x} 2 \_4$ & 0,651 & 0,000 & Valid \\
\hline & $\mathrm{x} 2 \_5$ & 0,739 & 0,000 & Valid \\
\hline \multirow[t]{5}{*}{$\begin{array}{c}\text { Kepuasan konsumen } \\
\text { ( Y ) }\end{array}$} & y_1 & 0,654 & 0,000 & Valid \\
\hline & y_2 & 0,751 & 0,000 & Valid \\
\hline & y_3 & 0,793 & 0,000 & Valid \\
\hline & y_4 & 0,486 & 0,000 & Valid \\
\hline & $\mathrm{y}_{-} 5$ & 0,555 & 0,000 & Valid \\
\hline
\end{tabular}

Sumber : Olah Data

Berdasarkan tabel diatas, dapat dilihat bahwa nilai signifikasi kurang dari 0,05 , sehingga seluruh data pada variabel kualitas produk di katakan valid, variabel harga dari semua pernytaan di katakan valid, sedangakan kepuasan konsumen variabel ini di katakan valid karena semua di bawah darii 0,05 . 


\section{Hasil uji reabilitas}

Setelah dilakukan uji validitas, maka selanjutnya dilakukan uji reliabilitas untuk mengetahui keandalan variabel. Suatu variabel dikatakan reliabel jika nilai cronbach alpha > 0.6 (Arikunto, 2014)

Adapun nilai uji reliabilitas pada variabel kualitas produk, harga terhadap kepuasan konsumen dapat dilihat pada tabel 3 dibawah ini,

Tabel 3. Hasil Uji Reliabilitas Pada Variabel kualitas produk, harga terhadap kepuasan konsumen

\begin{tabular}{|c|c|c|}
\hline Variabel & Alpha cronbach & Keterangan \\
\hline Kualitas produk ( x1 ) & 0,754 & Reliable \\
\hline harga ( x2 ) & 0,795 & Reliable \\
\hline Kepuasan konsumen ( y ) & 0,661 & Reliable \\
\hline
\end{tabular}

Sumber : Olah Data

Berdasarkan tabel diatas dapat dinyatakan bahwa nilai cronbach alpha seluruh variabel lebih besar dari 0.6 yang artinya seluruh variabel adalah reliabel.

\section{Uji Normalitas}

Nilai signifikansi yang didapat dari uji Kolmogorov-Smirnov adalah 0,592 yang berarti residual berdistribusi normal karena nilai tersebut lebih dari 0,05 .

\section{Uji Multikolinearitas}

Nilai VIF semua variabel independen berada di bawah 10 dan nilai tolerance yang dimiiliki semua variabel independen berada di atas 0,1 yang dapat diartikan bahwa tidak terjadi multikolinearitas dalam model regresi.

\section{Uji Heteroskedastisitas}

Nilai signifikansi semua variabel independen berada di atas 0,05 yang dapat disimpulkan bahwa tidak terjadi heteroskedastisitas

\section{Uji F}

Tabel 4 uji $\mathrm{f}$

\begin{tabular}{|cc|c|c|c|c|c|}
\hline & & Sum of \\
Model & Squares & df & Mean Square & F & Sig. \\
\hline 1 & Regression & 81.172 & 2 & 40.586 & 4.399 & $.016^{\mathrm{a}}$ \\
& Residual & 618.200 & 67 & 9.227 & & \\
& Total & 699.371 & 69 & & & \\
\hline
\end{tabular}

Sumber : Olah Data 
Nilai signifikansi pada uji $\mathrm{F}$ adalah 0,000 yang dapat diartikan bahwa variabel kualitas produk (X1), harga (X2) memberi pengaruh variabel kepuasan konsumen (Y) secara simultan karena nilai signifikansi $<0,05$. Berdasarkan tabel diatas menunjukkan bahwa nilai signifikansi sebesar $0,000<0,05$, serta nilai $\mathrm{F}$ hitung sebesar 4.399 dimana lebih besar dari nilai $\mathrm{F}$ tabel yang mempunyai nilai 2.47. Artinya variabel Kualitas produk dan harga berpengaruh secara simultan terhadap kepuasan konsumen. Oleh karena itu pengusaha harus mempertahankan Kualitas produk supaya terus mendapat kepercayaan dari pelanggan.

\section{Uji t}

Selanjutnya melakukan uji t untuk mengetahui apakah variabel $\mathrm{X} 1, \mathrm{X} 2$, memiliki pengaruh secara parsial terhadap variabel $\mathrm{Y}$.

Pengujian dilakukan dengan menggunakan nilai signifikan 0,05 , jika nilai signifikan > 0,05 maka hipotesis di tolak, dan jika nilai signifikan $\leq 0,05$ maka hipotesis diterima.

Nilai signifikansi untuk setiap variabel ada di bawah 0,05 yang dapat diartikan bahwa variabel kualitas produk (X1), harga (X2) tidak berpengaruh pengaruh secara parsial terhadap variabel kepuasan konsumen (Y).

\section{Uji regresi}

Tabel 5 Regresi

\begin{tabular}{|c|c|c|c|c|c|}
\hline \multirow{2}{*}{ Model } & \multicolumn{2}{|c|}{$\begin{array}{c}\text { Unstandardized } \\
\text { Coefficients }\end{array}$} & $\begin{array}{c}\text { Standardized } \\
\text { Coefficients }\end{array}$ & & \\
\cline { 2 - 5 } & $\mathrm{B}$ & Std. Error & Beta & $\mathrm{t}$ & Sig. \\
\hline \multirow{2}{*}{$1 \quad \begin{array}{c}\text { (Constant) } \\
\text { Kualitas } \\
\text { produk } \\
\text { harga }\end{array}$} & 9.607 & 1.675 & & 5.734 & .000 \\
& .210 & .097 & .271 & 2.287 & .025 \\
& .108 & .085 & .150 & 1.262 & .211 \\
\hline
\end{tabular}

Dari data tabel 5 menunjukkan nilai Sc, Beeta kualitas produk sebesar 0,271 sedangkan harga sebesar 0,150 maka bisa dilihat kualitas produk yang berpnegaruh paling dominan terhadap kepuasan konsumen

\section{Uji Koefisien Determinasi (R2)}

Uji koefisien determinasi digunakan untuk mengetahui seberapa besar variabel X1, X2, memiliki pengaruh terhadap variabel Y. Pada penelitian ini, nilai uji koefisien determinasi dapat dilihat pada tabel 5 dibawah ini, 
Tabel 6. Hasil Uji Koefisien Determinasi

Model Summary ${ }^{\mathbf{b}}$

\begin{tabular}{|l|c|r|r|r|r|r|r|r|r|r|}
\hline Mod & $\mathrm{R}$ & $\mathrm{R}$ & Adjust & Std. Error of \\
el
\end{tabular}

a. Predictors: kualitas produk, harga

b. Dependent Variable: kepuasan konsumen

Dari hasil uji koefisien determinasi diatas, didapatkan hasil nilai R Square sebesar 0,482 artinya variabel kualitas produk dan harga memiliki pengaruh sebesar 53,8\% terhadap pengambilan keputusan. Sedangkan 46,2\% dipengaruhi oleh variabel lain

\section{Kesimpulan}

Hasil dari penelitian ini, didapatkan beberapa kesimpulan yaitu,

a. Variabel kualitas produk dan harga memiliki pengaruh secara simultan terhadap kepuasan konsuemn, dibuktikan dengan dengan nilai signifikan kurang dari 0,05 menghasilkan nilai F hitung yang lebih besar dari $\mathrm{F}$ tabel.

b. Variabel kualitas produk dan harga berpengaruh secara parsial terhadap kepuasan konsuemn, karena memiliki nilai $\mathrm{t}$ hitung yang lebih besar dari $\mathrm{t}$ tabel dan nilai signifikan lebih kecil dari 0,05, sedangkan place dan harga tidak berpengaruh secara parsial terhadap kepuasan konsumen, karena memiliki t hitung yang lebih kecil dari t tabel dan nilai signifikansi lebih besar dari 0,05 .

c. Didapatkan hasil $53,8 \%$ pengaruh variabel kualitas produk dan harga terhadap kepuasan konsumen, sehingga 46,2\% pengaruhnya diakibatkan oleh faktor lain.

\section{Daftar pustaka}

Ghozali , Imam 2005, aplikasi multivariate program spss, semarang : badan penerbit UNDIP Jahanshahi, Asghar Afshar., et al. 2011. Study the Effects of Customer Service and Produk Quality on Customer Satisfaction and Loyalty. International Journal of Humanities and Social Science vol.1 no.7 June 2011.

Kuncoro, Prof Mudrajad. 2013. Metode Riset Untuk Bisnis \& Ekonomi. Bagaimana Meneliti dan Menulis Tesis?. Edisi 4. Penerbit Erlangga.

Kotler dan Keller. (2008)“Manajemen Pemasaran”. Edisi ketiga belas. Jakarta : Penerbit PT Prehallindo.

Lonardo dan Yasintha Soelasih. 2014. Analisis Pengaruh Kualitas Produk, Harga, dan Lingkungan Fisik Perusahaan Kue Lapis Legit XYZ Terhadap Kepuasan Konsumen Dalam Membangun Word of Mouth Positif. Jurnal Manajemen vol.11 no.1 Mei 2014.

Lenzun, Jessica J, James D.D Massie dan Decky Adare. 2014. Pengaruh Kualitas Produk, Harga dan Promosi Terhadap Kepuasan Pelanggan Kartu Prabayar Telkomsel. Jurnal EMBA vol.2 no.3 September 2014. 
Manus, Fanly W dan Bode Lumanauw. 2015. Kualitas Produk, Harga dan Kualitas Layanan, Pengaruhnya Terhadap Kepuasan Pelanggan Kartu Prabayar Tri di Keluarahan Wawalintouan Tondano Barat. Jurnal EMBA vol.3 no.2 Juni 2015.

Nugroho, Dwi Mulyono. 2015. Pengaruh Kualitas Pelayanan, Kualitas Produk Layanan, dan Harga Produk Layanan Terhadap Kepuasan Pelanggan Serta Dampaknya Terhadap Loyalitas Pelanggan Prabayar Telkomsel. Jurnal OE vol. 7 no.2 Juli 2015.

Umar 2002, metedologi penelitian aplikasi dalam pemasaran , Jakarta PT. gramedia

Putro, Shandy Widjoyo., et al. 2014. Pengaruh Kualitas Layanan dan Kualitas Produk Terhadap Kepuasan Pelanggan dan Loyalitas Konsumen Restoran Happy Garden Surabaya. Jurnal Manajemen Pemasaran vol.2 no.1 Tahun 2014.

Priyatno, Duwi. 2013. Analisis Korelasi, Regresi dan Multivariate dengan SPSS. Penerbit Gava Media.

Saleleng, Nia C.M., Christoffel Kojo dan Merlyn Karuntu. 2014. Kualitas Produk dan Kualitas Pelayanan Pengaruhnya Terhadap Kepuasan Pelanggan Kartu Prabayar Telkomsel. Jurnal EMBA vol.2 no.3 September 2014.

Tjiptono ( 2016) pemasaran jasa yogyakarta andi

Sugiyono. 2013. Metode Penelitian Manajemen. Bandung: Penerbit Alfabeta.

Weenas, Jackson R.S. 2013. Kualitas Produk, Harga, Promosi, dan Kualitas Pelayanan Pengaruhnya Terhadap Keputusan Pembelian Spring Bed Comforta. Jurnal EMBA vol.1 no.4 Desember 2013.

Wibowo. 2014. Manajemen Kinerja Edisi Keempat. Jakarta: PT. Rajagrafindo Persada.

Zakaria, Shandy Ibnu dan Sri Rahayu Tri Astuti. 2013. Analisis Faktor-faktor yang Mempengaruhi Kepuasan Konsumen Terhadap Pengguna Jasa Transportasi (Studi Kasus Pada Pengguna Bus Trans Jogja di Kota Yogyakarta). Diponegoro Journal of Management vol.2 no.3 Tahun 2013. 